\title{
Oral glucose supplementation improved semen quality and constituents of seminal and blood plasma of NZW buck rabbits in the subtropics
}

This article was published in the following Dove Press journal:

Open Access Animal Physiology

17 November 2010

Number of times this article has been viewed

Youssef A Attia'

A E Abd El Hamid'

Fulvia Bovera ${ }^{2}$

Mohamed El-Sayed'

'Department of Animal and Poultry Production, Faculty of Agriculture,

Damanhour University, Egypt;

${ }^{2}$ Department of Scienze Zootecniche e Ispezione degli Alimenti, University of Naples Federico II, Napoli, Italy
Correspondence: Youssef A Attia Department of Animal and Poultry Production, Faculty of Agriculture, Damanhour University, Egypt. Tel +20 10 3753095

Fax +20453316535

Email yfat_alexu40@hotmail.com

\begin{abstract}
The effect of different levels of oral glucose supplementation on reproductive performance of New Zealand white buck rabbits was studied on 12 bucks aged 6-7 months, randomly divided among four groups from February to September. The treatments consisted of supplementing drinking water with 0 (control), 2.5, 5, and $10 \mathrm{~g}$ of glucose/L, respectively. Semen was collected twice weekly from April through September. Three samples of blood and seminal plasma were collected for each treatment during August. Semen quality, biochemical constituents of seminal and blood plasma, and testosterone were studied. Oral glucose supplementation of 5 or $10 \mathrm{~g} / \mathrm{L}$ of drinking water significantly increased semen volume, sperm motility, sperm concentration, live sperm percentage, total sperm output, and total live sperm output and significantly decreased abnormal sperm percentage as compared to the control group. Addition of glucose at $5 \mathrm{~g} / \mathrm{L}$ water significantly increased blood plasma total protein, albumin, glucose, alanine aminotransferase, and testosterone hormone compared to the control group.
\end{abstract}

Keywords: rabbit, glucose, semen quality, seminal and blood plasma

\section{Introduction}

Rabbit meat (or other) is increasingly becoming a source of animal protein. The negative effects of heat stress on rabbit bucks include decreased semen quality, essential biochemical constituents of seminal, and blood plasma, and increased respiration rate, temperature of ear, rectum and skin, and water consumption. ${ }^{1-3}$ These effects have been attributed to the decrease in hormone profile eg, androgen and thyroid hormone, ${ }^{4,5}$ and focal degeneration in both seminiferous tubules and interstitial cells. ${ }^{6}$

Glucose is the principal metabolic fuel used by the growing embryo, fetus, and neonate $;^{7}$ the principal precursor for milk lactose and de novo synthesis of milk fat ${ }^{8}$ and the precursor of vitamin $\mathrm{C}$, which is well known as an antistressor. ${ }^{9}$ On the other hand, rabbits raised during summer season in Egypt (average temperature $31 \pm 5^{\circ} \mathrm{C}$ ) exhibited a significant decrease in serum glucose concentration. ${ }^{5}$

Productive and reproductive performance of rabbits during heat stress has been investigated extensively. However, no study to the best of our knowledge has addressed the possibility that glucose supplementation could improve productive and reproductive performance of rabbits exposed to heat stress due to decreased availability of glucose as a principal fuel for different metabolic and functional body processes. Thus, the present work aimed to study the effect of different concentrations of oral glucose diluted in drinking water on productive and reproductive performance of New Zealand White (NZW) buck rabbits. 


\section{Material and methods}

\section{Animal feeding and treatments}

Twelve NZW bucks aged 6-7 months and with an average live body weight of $3432 \pm 9.7 \mathrm{~g}$ were used for this study. The bucks were divided into four experimental groups, with an equal number in each $(n=3)$. The first group was kept without oral glucose supplementation and served as a control. The other three experimental groups were given drinking water supplemented with glucose $(2.5,5$, and $10 \mathrm{~g}$ glucose/L). The experimental period spanned February, March, April (moderate climate: $16.1^{\circ} \mathrm{C} ; 59.4 \%$ relative humidity (RH)), May, June, July, August, and September (hot climate: $27.9^{\circ} \mathrm{C} ; 53.2 \% \mathrm{RH}$ ). The total number of semen samples in all treatment groups was 576 samples. Semen was collected twice weekly from April through September by using an artificial vagina.

\section{Housing condition}

The animals were raised in flat deck batteries (Italian type) with universal specifications. Batteries were kept under hygienic control and accommodated with feeders to provide animals with pelleted rations and automatic freshwater drinkers. All batteries were located in a naturally ventilated windowed house. The buck rabbits were fed on a basal pelleted ration with principal chemical-nutritional characteristics (on a dry matter basis) of: $17 \%$ crude protein, $2,600 \mathrm{kcal}$ of digestible energy $/ \mathrm{kg}$, and $14 \%$ crude fibre. Feed and fresh water were offered ad libitum to the rabbits.

\section{Criteria of response}

Semen volume, sperm motility, sperm concentration, abnormal sperm percentage, total sperm output, and total live sperm output were studied. ${ }^{10}$

Three samples of blood and seminal plasma were collected for each treatment in August, four months after starting the experiment. Blood samples $(3-5 \mathrm{~mL})$ were collected in the morning, before feeding, from the marginal ear vein of each experimental buck, under vacuum in heparinized tube. Blood and semen samples were immediately centrifuged at 3,000 rpm for 10 minutes and plasma was separated, frozen at under $-20^{\circ} \mathrm{C}$, and kept for assaying using a calorimetric assay kit following the methodology suggested by the procedures. Plasma total protein, albumin, and glucose (bioMérieux, Marcy l'Etoile, France); total lipid and cholesterol (Boehringer Ingelheim $\mathrm{GmbH}$, Ingelheim, France); alanine aminotransferase (ALT) and aspartate aminotransferase (AST) (BioSystems, Barcelona, Spain); and testosterone (Biocon, Bangalore, India) were determined. Plasma globulin was determined from the difference between plasma total protein and plasma albumin.

\section{Statistical analysis}

The data were analyzed by least squares maximum likelihood method of analysis, ${ }^{11}$ using SPSS software (version 8; SPSS Inc., Chicago, IL) according to the following model:

$$
Y_{i j}=\mu+\alpha_{j}+e_{i}
$$

where $Y=$ the dependent variable; $\mu=$ general mean; $\alpha=$ glucose effect; $e=$ random error.

All percentages were subjected to logarithmic transformation $(\log 10 x+1)$ to normalize data distribution. Duncan's new multiple range test ${ }^{12}$ was used for the multiple comparisons.

\section{Results Biochemical constituents of seminal plasma}

Oral glucose supplementation had no significant effect on total lipids and AST and ALT enzymes, showing that glucose up to $10 \mathrm{~g}$ glucose/L did not induce cell injury (Table 1).

\section{Semen quality traits}

A $5 \mathrm{~g} / \mathrm{L}$ concentration of oral glucose supplementation significantly improved $(P<0.01)$ the semen quality of NZW buck rabbits (Table 2). Sperm motility (\%), sperm concentration $\left(\times 10^{6} / \mathrm{mL}\right)$, total sperm output $\left(\times 10^{6} /\right.$ ejaculate $)$, and total live sperm output increased significantly $(P<0.01)$, while abnormal sperm and dead spermatozoa (\%) decreased significantly in the semen of bucks administered with $5 \mathrm{~g}$ glucose/L water compared to those of the control group. In addition, $10 \mathrm{~g}$ glucose/L water induced similar effects, showing that $5 \mathrm{~g}$ glucose/L water was sufficient. However, ejaculate volume was not affected by administration of 5 and $10 \mathrm{~g}$ glucose/L water compared to the control (Table 2).

A negative effect was quoted in ejaculate volume $(-33.3 \%)$, total sperm output $(-35.4 \%)$, and total live sperm output (-31.3\%) for bucks supplemented with $2.5 \mathrm{~g}$ glucose/L as compared to the unsupplemented control. In addition, the reduction in these criteria of semen was significant compared to the other levels of glucose. On the other hand, $2.5 \mathrm{~g}$ glucose $/ \mathrm{L}$ water resulted in similar $(P<0.05)$ sperm motility and sperm concentration to those of the unsupplemented control and $10 \mathrm{~g}$ glucose/L water, indicating 
Table I Biochemical constituents of seminal plasma by different glucose level of NZW buck rabbits (LSM \pm SE)

\begin{tabular}{|c|c|c|c|c|c|}
\hline & \multirow[t]{2}{*}{ Control } & \multicolumn{3}{|c|}{ Glucose concentration (g/L) } & \multirow[t]{2}{*}{$P$-value } \\
\hline & & 2.5 & 5 & 10 & \\
\hline Total protein $(g / d L)$ & $5.63^{b} \pm 0.41$ & $6.13^{b} \pm 0.32$ & $8.23^{a} \pm 0.78$ & $9.17^{\mathrm{a}} \pm 0.73$ & 0.05 \\
\hline Albumin $(\mathrm{g} / \mathrm{dL})$ & $2.63 \pm 0.23$ & $2.77 \pm 0.22$ & $3.27 \pm 0.19$ & $3.30 \pm 0.26$ & NS \\
\hline Globulin (g/dL) & $3.00^{\mathrm{b}} \pm 0.55$ & $3.37^{b} \pm 0.52$ & $4.97^{\mathrm{ab}} \pm 0.96$ & $5.87^{\mathrm{a}} \pm 0.61$ & 0.05 \\
\hline Total lipid (g/L) & $1.30 \pm 0.12$ & $1.37 \pm 0.09$ & $1.73 \pm 0.22$ & $1.57 \pm 0.09$ & NS \\
\hline Cholesterol (mg/dL) & $74.6^{b} \pm 3.8$ & $79.2^{b} \pm 4.21$ & $104.2^{\mathrm{a}} \pm 8.6$ & $117.5^{\mathrm{a}} \pm 3.6$ & 0.01 \\
\hline AST (U/L) & $17.47 \pm 2.29$ & $15.40 \pm 1.04$ & $|2.57 \pm| .4 \mid$ & $12.57 \pm 0.45$ & NS \\
\hline $\mathrm{ALT}(\mathrm{U} / \mathrm{L})$ & $30.73 \pm 1.01$ & $29.10 \pm 1.23$ & $26.00 \pm 2.20$ & $26.90 \pm 1.51$ & NS \\
\hline Testosterone (ng/mL) & $12.43^{b} \pm 0.63$ & $13.20^{\mathrm{b}} \pm 0.70$ & $17.93^{\mathrm{a}} \pm 0.95$ & $18.43^{a} \pm 0.75$ & 0.01 \\
\hline
\end{tabular}

Notes: Means within the same row not having similar superscripts $\left({ }^{a, b, c}\right)$ are significantly different $(P<0.05)$.

Abbreviations: LSM, least squares mean; SE, standard error; NZW, New Zealand White; NS, not significant; AST, aspartate aminotransferase; ALT, alanine aminotransferase; U/L, units per litre.

that $2.5 \mathrm{~g}$ glucose/L did not affect these characteristics and was less efficiently compared to $5 \mathrm{~g}$ glucose/L. Glucose significantly reduced abnormal sperm and dead spermatozoa, while it did not affect sperm concentration compared to the unsupplemented control. This effect was linear up to $5 \mathrm{~g}$ glucose/L water and stabilized afterwards.

\section{Biochemical constituents of blood plasma}

Plasma globulin and cholesterol levels did not increase significantly compared with the control (Table 3 ). It was found that 5 and $10 \mathrm{~g}$ glucose/L water significantly increased plasma albumin, total protein, glucose, total lipid, AST, and ALT enzyme compared to the control group. On the other hand, plasma albumin level was increased significantly $(P<0.01)$ due to $2.5 \mathrm{~g}$ glucose $/ \mathrm{L}$ water when compared to the unsupplemented group, and this increment was not significant afterwards. However, $2.5 \mathrm{~g}$ glucose/L water did not significantly affect plasma total protein, glucose, total lipids, AST, and ALT plasma level. However, there was a stepwise increase in plasma testosterone with increasing level of glucose supplementation.

\section{Discussion}

Supplementation of 5 or $10 \mathrm{~g}$ glucose/L in drinking water significantly improved semen qualities and increased seminal plasma total protein, cholesterol, and testosterone, while only 10 g glucose significantly increased semen globulin level. This indicated that $5 \mathrm{~g}$ glucose $/ \mathrm{L}$ water was adequate. The increase in seminal plasma testosterone due to 5 and $10 \mathrm{~g}$ glucose/L water disagrees with the results reported by Attia et $\mathrm{al}^{13}$ who indicated that plasma testosterone was not affected by energy allotments to broiler breeder males. Similarly, Hotzel et $\mathrm{a}^{14}$ found that in rams infused with gonadotropinreleasing hormone $(\mathrm{GnRH})$, gonadotrophin secretion was not affected by feeding high or low-diet for maintenance of body weight, and the patterns of secretion of luteinizing hormone (LH) and follicle-stimulating hormone (FSH) were similar to those in saline-infused rams fed the high diet. However, Brown ${ }^{15}$ reported that reproductive functions in young animals appear to be more susceptible to dietary restrictions of energy and protein than in the adult, and severe feed restriction may even result in permanent damage to gonadal and neural tissue. Martin and Walkden-Brown ${ }^{16}$ concluded

Table 2 Semen quality traits by different oral glucose administration of NZW buck rabbits (LSM \pm SE)

\begin{tabular}{|c|c|c|c|c|c|}
\hline & \multirow[t]{2}{*}{ Control } & \multicolumn{3}{|c|}{ Glucose concentration (g/L) } & \multirow[t]{2}{*}{ P-value } \\
\hline & & 2.5 & $\mathbf{5}$ & 10 & \\
\hline Ejaculate volume $(\mathrm{mL})$ & $0.60^{\mathrm{a}} \pm 0.003$ & $0.40^{\mathrm{b}} \pm 0.003$ & $0.65^{\mathrm{a}} \pm 0.005$ & $0.63^{\mathrm{a}} \pm 0.004$ & 0.01 \\
\hline Sperm motility (\%) & $74.2^{\mathrm{b}} \pm 3.2$ & $70.4^{b} \pm 2.3$ & $82.5^{\mathrm{a}} \pm 0.8$ & $77.5^{\mathrm{ab}} \pm 2.4$ & 0.01 \\
\hline Abnormal spermatozoa (\%) & $18.9^{\mathrm{a}} \pm 0.7$ & $15.3^{b} \pm 0.8$ & $10.8^{c} \pm 0.7$ & $9.39^{c} \pm 0.63$ & 0.01 \\
\hline Dead spermatozoa (\%) & $25.9^{a} \pm 0.9$ & $22.5^{\mathrm{b}} \pm 1.1$ & $15.7^{c} \pm 1.1$ & $15.2^{c} \pm 1.0$ & 0.01 \\
\hline Sperm concentration $\left(\times 10^{6} / \mathrm{mL}\right)$ & $193.4^{c} \pm 12.1$ & $198.6^{\mathrm{bc}} \pm 10.5$ & $279.6^{\mathrm{a}} \pm 11.2$ & $229.7^{b} \pm 10.4$ & 0.01 \\
\hline Total sperm output (× 106/ejaculate) & $117.9^{b} \pm 8.6$ & $76.24^{c} \pm 6.86$ & $179.6^{a} \pm 14.0$ & $142.7^{b} \pm 10.9$ & 0.01 \\
\hline Total live sperm output (× 10\%/ejaculate) & $87.1^{b} \pm 6.7$ & $59.9^{c} \pm 6.0$ & $153.4^{a} \pm 12.5$ & $129.0^{\mathrm{a}} \pm 10.9$ & 0.01 \\
\hline
\end{tabular}

Notes: Means within the same row not having similar superscripts $\left({ }^{a, b, c}\right)$ are significantly different $(P<0.05)$.

Abbreviations: LSM, least squares mean; SE, standard error; NZW, New Zealand White. 
Table 3 Biochemical constituents of blood plasma by different oral glucose administration of NZW buck rabbits (LSM \pm SE)

\begin{tabular}{|c|c|c|c|c|c|}
\hline & \multirow[t]{2}{*}{ Control } & \multicolumn{3}{|c|}{ Glucose concentration (g/L) } & \multirow[t]{2}{*}{$P$-value } \\
\hline & & 2.5 & 5 & 10 & \\
\hline Total protein (g/dL) & $6.37^{b} \pm 0.26$ & $7.13^{\mathrm{ab}} \pm 0.34$ & $8.23^{a} \pm 0.50$ & $8.58^{a} \pm 0.76$ & 0.05 \\
\hline Albumin (g/dL) & $4.02^{b} \pm 0.05$ & $4.16^{a} \pm 0.06$ & $4.98^{\mathrm{a}} \pm 0.27$ & $5.61^{a} \pm 0.38$ & 0.01 \\
\hline Globulin (g/dL) & $2.35 \pm 0.24$ & $2.97 \pm 0.31$ & $3.25 \pm 0.25$ & $2.97 \pm 0.41$ & NS \\
\hline Glucose (mg/dL) & $76.4^{b} \pm 2.49$ & $80.3^{b} \pm 5.29$ & $100.0^{a} \pm 3.59$ & $107.4^{a} \pm 2.80$ & 0.01 \\
\hline Total lipid (g/L) & $3.32^{b} \pm 0.01$ & $3.94^{b} \pm 0.37$ & $3.56^{\mathrm{ab}} \pm 0.32$ & $4.54^{\mathrm{a}} \pm 0.28$ & 0.05 \\
\hline Cholesterol (mg/dL) & $|12.2 \pm 1.7|$ & $122.5 \pm 3.17$ & $122.7 \pm 1.10$ & $|23.7 \pm 2.3|$ & NS \\
\hline AST (U/L) & $10.88^{b} \pm 0.6 \mid$ & $12.26^{\mathrm{ab}} \pm 1.22$ & $12.26^{\mathrm{ab}} \pm 0.23$ & $13.84^{a} \pm 0.87$ & 0.01 \\
\hline $\operatorname{ALT}(\mathrm{U} / \mathrm{L})$ & $19.28^{b} \pm 0.92$ & $20.78^{b} \pm 0.47$ & $25.32^{\mathrm{a}} \pm 1.17$ & $26.78^{a} \pm 1.22$ & 0.01 \\
\hline Testosterone $(\mathrm{ng} / \mathrm{mL})$ & $3.50^{c} \pm 0.26$ & $4.1 I^{b c} \pm 0.49$ & $4.92^{\mathrm{ab}} \pm 0.11$ & $5.57^{a} \pm 0.45$ & 0.05 \\
\hline
\end{tabular}

Notes: Means within the same row not having similar superscripts $\left({ }^{\mathrm{a}, \mathrm{b}, \mathrm{c}}\right)$ are significantly different $(P<0.05)$.

Abbreviations: LSM, least squares mean; SE, standard error; NZW, New Zealand White; NS, not significant; AST, aspartate aminotransferase; ALT, alanine aminotransferase; U/L, units per litre.

that energetic components of the diet, rather than the protein content, seem to be responsible for affecting gonadotrophin secretion in rams. In the gonads, the gametogenic tissue responds rapidly to changes in nutrition, but the endocrine compartments are less affected.

The decrease in abnormal sperm and dead spermatozoa due to oral glucose administration suggests that glucose is a limiting factor (fuel) in the sperm maturation and development, and glucose administration improves carbohydrate status. ${ }^{17,18}$ Rigau et al ${ }^{19}$ reported that glucose increased sperm motility, cyclic adenosine 5-phosphate, and ATP and decreased the respiration rate. In chickens, Bramwell et $\mathrm{l}^{20}$ following the early research of Attia et a ${ }^{13,21}$ concluded that decreasing energy allotments decreased sperm concentration and total live sperm per $\mathrm{mL}$ of ejaculate, whereas it had no significant effect on ejaculate volume or percentage dead sperm. These results indicated that NZW bucks could tolerate 5 and $10 \mathrm{~g}$ glucose/L water. Glucose tolerance was reported to be affected by strain, species, health condition, pancreatic functions, and pregnancy. ${ }^{22}$ In this respect, Kamuro et $\mathrm{al}^{23,24}$ found that liver glycogen content in animals that received no glucose was significantly lower than that of the $0.2 \mathrm{~g} / \mathrm{kg} / \mathrm{h}$ and the results suggested that intraoperative glucose supplementation is effective in preventing glycogen depletion. To avoid glucose overloading, the optimal dose is $0.1-0.2 \mathrm{~g} / \mathrm{kg} / \mathrm{h}$. Furthermore, the positive impact of glucose on semen quality could be attributed to its role as a precursor of vitamin $\mathrm{C}$, which is well known as an antistressor, and decreased gluconeogenesis. ${ }^{9}$ In addition, Attia et a ${ }^{13}$ reported that ejaculate volume was generally improved in high (above the requirements) and intermediate energy (adequate) allotments groups when compared to the low energy (below the requirements) allotment group, although there was no clear trend in packed cell volume (PCV) of semen and plasma testosterone concentration of broiler breeder males. However, Attia and Badawy ${ }^{25}$ found that semen quality (semen volume, viscosity, dead, abnormality, liveability, mass motility, PCV, and percent male producing semen) of Silver and Golden Montazah chicken breeder males were not significantly affected by dietary energy levels. This could be attributed to the strain of birds as heavy broiler breeders were used in the first study and light strains were used in the second one.

The increase in serum glucose observed here is in agreement with the results of Rubio et $\mathrm{al}^{26}$ who reported that intraperitoneal glucose administration increased serum glucose $(50 \%$ dextrose) and insulin, while having no effect on serum growth hormone. However, Matsuno et $\mathrm{al}^{27}$ indicated that plasma glucose and insulin values were not significantly affected by dietary glucose level in rat diets. In partial agreement with the present results, Atta ${ }^{28}$ analyzed the blood plasma of broiler chicks and reported that D-glucose did not affect plasma albumin and total lipid. The increase in serum testosterone due to increasing glucose level is in contrast to the results reported by Attia et $\mathrm{al}^{13}$ who indicated that plasma testosterone was not affected by different dietary energy allotments in broiler breeder males. Along the same line, Hotzel et a ${ }^{14}$ found that in GnRH-infused rams, gonadotrophin secretion was not affected by high or low-diet for maintenance of body weight and the patterns of secretion of LH and FSH were similar to those in saline-infused rams fed the high diet. However, Brown ${ }^{15}$ concluded that restricted feed intake in adult animals can reduce androgen secretion. Moreover, Martin and Walkden-Brown ${ }^{16}$ concluded that in the gonads, the gametogenic tissue responds rapidly to changes in nutrition, but the endocrine compartments are less affected. This contradiction to nutrition in androgen response could be attributed to species differences. 


\section{Conclusion}

Glucose supplementation at $5 \mathrm{~g}$ glucose/L water in NZW buck rabbits significantly increased total protein and testosterone in serum and seminal plasma and these results concurred with the improving production and quality of semen observed under the subtropical conditions of Egypt.

\section{Disclosure}

The authors report no conflicts of interest in this work.

\section{References}

1. Daader AH, Askar AA, Abd El-Monem UM. Influence of temperaturehumidity index values on the performance of New Zealand White doe rabbits. Egypt J Rab Sci. 2003;13:157-170.

2. Ahmed NA, Elfar AA, Sakr OG. Effect of buck and doe-gathering on sexual and maternal behavior, serum $\mathrm{E}_{2}$ and $\mathrm{P}_{4}$ and reproductive performance of NZW doe rabbits. In: Proceedings of the 4th International Conference on Rabbit Production in Hot Climate; 2005; Sharm El-Sheikh, Egypt. p. 169-175.

3. Ahmed SS, EL-Gendy KM, Sahan MA, Tawfeek MI, EL-Kelawy HM. Response of rabbits to diets containing water-cress (nasturtium officianale) as a natural feed additives. In: Proceedings of the $3 \mathrm{rd}$ International Poultry Conference; 2005 Apr 4-7; Hurghada, Egypt. p. 491-505.

4. Boiti C, Chiericato GM, Filotto V, Canali C. Effect of higher environmental temperature on plasma testosterone, cortisol, T3 and T4 in the growing rabbits. In: Proceeding of the 5th World Rabbit Congress; 1992; Oregon State University, Oregon, USA. p. 447-455.

5. Marai IFM, Habeeb AA, Gad AE. Tolerance of imported rabbits grown as meat animals to hot climate and saline drinking water in the subtropical environment of Egypt. Anim Sci. 2005;81:115-123.

6. Okab AB, El-Banna SG, Yehiti MAH. Seminal characteristics and gonadal histochimical changes of male and female Red Baladi rabbits throughout seasons of the year. Egypt J Rab Sci. 2004;14:1-28.

7. Koski KG, Hill FW. Evidence for a critical period during late gestation when maternal dietary carbohydrate is essential for survival of newborn rats. J Nutr. 1990;120:1016-1027.

8. Koski KG, Hill FW, LÖnnerdal B. Altered lactational performance in rats fed low carbohydrate diets and its effect on growth of neonatal rat pups. J Nut. 1990;120:1028-1036.

9. Cafantaris B. Update of vitamin C application in poultry. 1990; 4th Symposium Rovigypt Poultry Seminar.

10. Boiti C, Castellini C, Besenfelder U, et al. Guidelines for the handling of rabbit bucks and semen. World Rab Sci. 2005;13:71-91.

11. Snedecor GW, Cochran GW. Statistical Methods. 6th ed. Ames: Iowa State University Press; 1982.

12. Duncan DB. Multiple range and multiple F-tests. Biometrics. 1955;11: $1-42$.
13. Attia YA, Burke WH, Yamani KA, Jensen LS. Energy allotments and reproductive performance of broiler breeders. 1. Males. Poul Sci. 1995; $74: 247-260$.

14. Hotzel MJ, Walkden-Brown SW, Blackberry MA, Martin GB. The effect of nutrition on testicular growth in mature Merino rams involves mechanisms that are independent of changes in GnRH pulse frequency. J Endocr. 1995;147:75-85.

15. Brown BW. A review of nutritional influences on reproduction in boars, bulls and rams. Reprod Nut Develop. 1994;342:89-114.

16. Martin GB, Walkden-Brown SW. Nutritional influences on reproduction in mature male sheep and goats. J Reprod Fert Supply. 1995;49: $437-449$.

17. Moran ET Jr. Effect of post hatch glucose on poults fed and fasted during yolk sac depletion. Poul Sci. 1989;68:1141-1147.

18. Engku EA, Zahan A, Forbes JM. Growth, food intake and energy balance of layer and broiler chickens offered glucose in the drinking water and the effect of dietary protein content. Br Poult Sci. 1989;30: 907-917.

19. Rigau T, Rivera M, Palomo MJ, et al. Differential effects of glucose and fructose on hexose metabolism in dog spermatozoa. Reprod. 2002;123: 579-591.

20. Bramwell RK, McDaniel CD, Burke WH, Howarth B. Influence of male broiler breeder dietary energy intake on reproduction and progeny growth. Poult Sci. 1996;75:767-775.

21. Attia YA, Yamani KA, Bruke WH. Daily energy allotments and reproductive performance of broiler breeder males. Poult Sci. 1993;72: 42-50.

22. Hay MF, Morales E, Soong R. Effect of maternal treatment with various agents on early embryonic development in the rabbit. In: Proceedings of the 5th International Congress on Animal Reproduction and Artificial Insemination; 1984; Trento, Italy. Rome: FAO. p. 309.

23. Kamuro H, Kodaira H, Shun-Ichi A, Ogawa R. Experimental study of efficacy and optimal dose of intraoperative glucose in rabbits under general anesthesia. J Anesthesia. 1996;10:140-143.

24. Kamuro H, Komorita N, Ogawa R. Optimal dose and duration of glucose administration during fasting period preceding surgery in rabbits. J Anesthesia. 2000;141:19-23.

25. Attia YA, Badawy NA. Effect of dietary energy levels on reproductive performance, semen quality and offspring growth of two local chicken breed males. Egyptian Poult Sci J. 1996;16:69-86.

26. Rubio JM, Hallford DM, Hawkins DE. Effect of glucose administration during the oestrous cycle on serum hormone profiles, MRNA for steriodogenic enzymes and breeding performance of Ewes. J Anim Sci. 1997;75:775-780.

27. Matsuno AY, Esrey KL, Perrault H, Koski K. Low intensity exercise and varying proportions of dietary glucose and fat modify milk and mammary gland composition and pup growth. J Nut. 1999;129:1167-1175.

28. Atta AM. Performance of broilers administrated with D-glucose during the post-hatch period. MSc Thesis, Faculty of Agriculture, Alexandria University. 2001.
Open Access Animal Physiology

\section{Publish your work in this journal}

Open Access Animal Physiology is an international, peer-reviewed, open access journal publishing original research, reports, reviews and commentaries on all areas of animal physiology. The manuscript management system is completely online and includes a very

\section{Dovepress}

quick and fair peer-review system. Visit http://www.dovepress.com/ testimonials.php to read real quotes from published authors. 